Revue bibliographique pour le domaine irano-aryen

\title{
Bernard O'Kane. Reconciliation or estrangement? Colophon and paintings in the TIEM Żafarnāma and some other controversial manuscripts
}

Nourane Ben Azzouna

\section{(2) OpenEdition \\ 1 Journals}

\section{Édition électronique}

URL : http://journals.openedition.org/abstractairanica/40801

DOI : 10.4000/abstractairanica.40801

ISSN : 1961-960X

Éditeur :

CNRS (UMR 7528 Mondes iraniens et indiens), Éditions de l'IFRI

\section{Édition imprimée}

Date de publication : 1 décembre 2013

ISSN : 0240-8910

\section{Référence électronique}

Nourane Ben Azzouna, « Bernard O'Kane. Reconciliation or estrangement? Colophon and paintings in the TIEM Żafarnāma and some other controversial manuscripts », Abstracta Iranica [En ligne], Volume 32-33 | 2013, document 307, mis en ligne le 01 juillet 2016, consulté le 05 octobre 2020. URL : http:// journals.openedition.org/abstractairanica/40801; DOI : https://doi.org/10.4000/abstractairanica. 40801

Ce document a été généré automatiquement le 5 octobre 2020.

Tous droits réservés 


\title{
Bernard O'Kane. Reconciliation or estrangement? Colophon and paintings in the TIEM Żafarnāma and some other controversial manuscripts
}

\author{
Nourane Ben Azzouna
}

\section{RÉFÉRENCE}

Bernard O'Kane. «Reconciliation or estrangement? Colophon and paintings in the TIEM Żafarnāma and some other controversial manuscripts». Muqarnas, 26, 2009, p. 205-227.

Cet article aborde une problématique rencontrée dans plusieurs manuscrits illustrés de la période de transition entre les époques timouride et safavide : l'incohérence entre le colophon qui indique un lieu et une date de production - en l'occurrence Herāt à la fin $\mathrm{du} \mathrm{XV}^{\mathrm{e}}$ s. - et le style des illustrations qui suggère un cadre spatio-temporel différent - Tabrīz, Šīrāz, Mašhad ou Herāt au XVI ${ }^{\mathrm{e}}$ s. - et il repose la question, déjà avancée par d'autres savants, de l'existence d'ateliers indépendants parallèlement à l'atelier royal timouride dirigé par Behzād (m.942/1537). L'A. propose d'enrichir ce débat en réexaminant une copie du Zaafarnāme de Šaraf al-Dīn 'Alī Yazdī (m. 858/1454) qui est datée de 891/1486 (Istanbul, Türk ve Islam Eserleri Müzesi, T. 1964) mais dont les peintures présentent des parallèles safavides. Il fait quelques remarques sur la calligraphie, l'enluminure et la reliure, avant d'étudier une à une les peintures. Il conclut que cinq d'entre elles peuvent être reliées à l'école de Herāt à la fin de la période timouride. En revanche, l'absence de nom de commanditaire et le programme iconographique empêchent d'attribuer le manuscrit à l'atelier royal. Il fut 
probablement commencé par un atelier indépendant à Herāt, mais inachevé puis complété par un atelier safavide.

\section{AUTEURS}

\section{NOURANE BEN AZZOUNA}

Agence France Muséums-Louvre, Abu Dhabi 